\title{
Using Infodemiology Metrics to Assess Public Interest in Liver Transplantation: Google Trends Analysis
}

Maria Effenberger ${ }^{1}$, MD; Andreas Kronbichler ${ }^{2}, \mathrm{PhD}$; Erica Bettac ${ }^{3}$, BSc; Felix Grabherr ${ }^{1}$, MD; Christoph Grander ${ }^{1}$, MD; Timon Erik Adolph ${ }^{1}$, PhD; Gert Mayer ${ }^{2}$, MD; Heinz Zoller ${ }^{1}$, MD; Paul Perco ${ }^{2}$, PhD; Herbert Tilg ${ }^{1}$, MD

${ }^{1}$ Department of Internal Medicine I, Gastroenterology, Hepatology, Endocrinology and Metabolism, Medical University of Innsbruck, Innsbruck, Austria

${ }^{2}$ Department of Internal Medicine IV, Nephrology and Hypertensiology, Medical University of Innsbruck, Innsbruck, Austria

${ }^{3}$ Department of Psychology, Washington State University Vancouver, Vancouver, WA, United States

Corresponding Author:

Herbert Tilg, MD

Department of Internal Medicine I, Gastroenterology, Hepatology, Endocrinology and Metabolism

Medical University of Innsbruck

Anichstrasse 35

Innsbruck, 6020

Austria

Phone: 4351250423539

Fax: 4351250423538

Email: herbert.tilg@i-med.ac.at

\section{Abstract}

Background: Liver transplantation (LT) is the only curative treatment for end-stage liver disease. Less than $10 \%$ of global transplantation needs are met worldwide, and the need for LT is still increasing. The death rates on the waiting list remain too high.

Objective: It is, therefore, critical to raise awareness among the public and health care providers and in turn increasingly acquire donors.

Methods: We performed a Google Trends search using the search terms liver transplantation and liver transplant on October 15, 2020. On the basis of the resulting monthly data, the annual average Google Trends indices were calculated for the years 2004 to 2018. We not only investigated the trend worldwide but also used data from the United Network for Organ Sharing (UNOS), Spain, and Eurotransplant. Using pairwise Spearman correlations, Google Trends indices were examined over time and compared with the total number of liver transplants retrieved from the respective official websites of UNOS, the Organización Nacional de Trasplantes, and Eurotransplant.

Results: From 2004 to 2018, there was a significant decrease in the worldwide Google Trends index from 78.2 in 2004 to 20.5 in $2018(-71.2 \%)$. This trend was more evident in UNOS than in the Eurotransplant group. In the same period, the number of transplanted livers increased worldwide. The waiting list mortality rate was $31 \%$ for Eurotransplant and 29\% for UNOS. However, in Spain, where there are excellent awareness programs, the Google Trends index remained stable over the years with comparable, increasing LT numbers but a significantly lower waiting list mortality (15\%).

Conclusions: Public awareness in LT has decreased significantly over the past two decades. Therefore, novel awareness programs should be initialized.

(J Med Internet Res 2021;23(8):e21656) doi: $\underline{10.2196 / 21656}$

\section{KEYWORDS}

digital medicine; search trends; public awareness; infodemiology; eHealth 


\section{Introduction}

\section{Background}

Liver transplantation (LT) remains to be the only curative therapy for patients affected by end-stage liver disease, cirrhosis with hepatocellular carcinoma, acute fulminant hepatic failure, hepatocellular carcinoma, hilar cholangiocarcinoma, and several metabolic disorders [1,2].

Each year, approximately 12,000 LTs are performed in Europe and the United States, with numbers significantly increasing over time [3]. At present, more than $70 \%$ of liver transplant recipients survive for at least 5 years, compared with $20 \%$ in the 1980s. Such statistics are especially encouraging, considering that transplanted patients tend to have more severe diseases [4]. Several factors increase the survival of patients with LT, including better control of disease before LT, improved surgical techniques and surgeons specialized in these techniques, improved organ preservation, and advanced immunosuppressive therapy regimens [5]. However, the improved success rate of LT has resulted in substantial organ shortages [4]. Such shortages have led to a prolonged time for patients on the waiting list and increased waiting list mortality [6-8].

In 2017, the median pretransplant waiting time among active waitlisted adults was 10 months in the Eurotransplant region and approximately 9 months in the United States [9]. Mortality on the list was $18.7 \%$ in the Eurotransplant region, which is comparable with the United States' $19.8 \%$ of listed patient deaths before transplantation. It is important to note that limited donor organs are available from deceased donors after brain death [6].

The discrepancy between available liver allografts and transplant candidates continues to increase globally. Significant efforts have been made to raise the donor pool in Europe and the United States, such as using extended criteria donor organs [10], inventing extracorporeal normothermic or hypothermic organ perfusion systems [11], and accepting liver allografts as donation after circulatory determination of death (DCDD) [12]. Despite these efforts, there remains no significant decrease in waiting list mortality. To close the gap between available organs and the number of patients in need of LT, a higher awareness and acceptance of the transplant and donor program in the general population, as well as among health care providers, is a potentially effective strategy.

Infodemiology is an emerging area of research among health informatics, health care professionals, and patients. Introduced in 2002 [13], the term infodemiology is defined as a new area of scientific research that holds great promise for improving public health by focusing on specific internet searches for user-contributed health-related content [13-15]. These searches track public opinion, behavior, attention, knowledge, and attitudes [16].

\section{Objectives}

The first study indicated a correlation between searches on the internet and incidence in the field of infectious diseases [17]. The number of infodemiological studies has increased over the past decade, and these studies have used Twitter and Google
[18]. Many researchers have used the infodemiological approach to study various health-related topics, for example, infectious diseases such as influenza or HIV/AIDS, chronic diseases such as multiple sclerosis, or patterns of smoking and tobacco use [19-27]. A particular interest in infodemiology has risen because of the ongoing COVID-19 pandemic [28], as research informs about the speed of misinformation [29], correlation between search behavior and COVID-19 related mortality [30], mental health issues [31], and pressing health care topics such as telehealth capacity of hospitals [32]. In addition, these data are becoming valuable tools for exploring human behavior. The advantage of infodemiology is that metrics are available in real time, which can provide quantitative and qualitative data while being automatically and inexpensively collected.

The analysis of internet search queries offers information on the extent of public attention, thereby reflecting the level of public awareness [33-36]. Google Trends is one of the most widely used tools for this purpose. It is not only used to study public interest in health care topics but also to predict disease occurrence and outbreaks [17,37,38].

In this study, we evaluated public interest in LT over time using Google Trends data and compared them with the number of transplanted livers reported from the United Network for Organ Sharing (UNOS), the Organización Nacional de Trasplantes (ONT), and the Eurotransplant regions.

\section{Methods}

\section{Retrieving Transplantation Numbers for UNOS, ONT, and Eurotransplant}

Data were retrieved by accessing the respective websites of the transplant organizations UNOS, ONT, and Eurotransplant [39-41]. We extracted information on living and deceased donors over a period of 15 years (2004-2018) for the following countries: the United States (UNOS), Spain (ONT), Austria, Belgium, Croatia, Germany, Hungary, Luxembourg, and the Netherlands (belonging to the Eurotransplant countries). No organs from executed prisoners were used in these transplant organizations.

\section{Retrieving Google Trends Data on LT}

The Google Trends tool was used on October 15, 2020, to retrieve data on internet user search activities in the context of LT [42]. Worldwide Google Trends indices were retrieved from January 2004 onward using the search terms, liver transplantation and liver transplant. We retrieved Google Trends indices for the United States, Spain, and European countries, in part included in the Eurotransplant network, namely Austria, Belgium, Croatia, Germany, Hungary, and the Netherlands. No Google Trends indices could be retrieved for Luxembourg and Slovenia. Whereas the worldwide search was performed in English, individual searches across non-English-speaking countries were performed in their respective official languages. We used individual search terms and combined the search terms yielding Google Trends results in larger queries, as listed in Table 1. On the basis of monthly data, annual average Google Trends indices were calculated for the years 2004 to 2018 and used to generate the line plots with 
the ggplot2 package of the statistical software R (version 3.4.1; $\mathrm{R}$ Foundation for Statistical Computing). It is important to note that none of the queries in the Google database for this study can be associated with a particular individual. The database does not retain information about the identity, IP address, or specific physical location of any user. The Spearman correlation coefficient was used to determine pairwise correlations between total liver transplant numbers per country and Google Trends indices.

Table 1. Google Trends search query listing (2004-present).

\begin{tabular}{lll}
\hline Region & Language & Google Trends search query \\
\hline Worldwide & English & liver transplantation and liver transplant \\
United States & English & liver transplantation and liver transplant \\
Spain & Spanish & trasplante de hígado, trasplante higado, and trasplante de higado \\
Belgium & French & transplantation hépatique and levertransplantatie \\
The Netherlands & Dutch & Levertransplantatie \\
Germany & German & Lebertransplantation \\
Austria & German & Lebertransplantation \\
Hungary & Hungarian & májátültetés and májtranszplantáció \\
Croatia & Croatian & transplantacija jetre \\
\hline
\end{tabular}

\section{Results}

\section{Google Trends and Trends for LT Worldwide}

The global Google Trends index for LT decreased from 73.8 to $36.6(-50.4 \%)$ between 2004 and 2014. In 2018, there was a slight upward trend in the LT index to $46.3(+27.5 \%$; Figure 1).
A similar trend was observed for the UNOS, with the Google Trends index dropping from 59.2 to $38.8(-34.5 \%)$ in 2014 and an upward trend since then to $50.3(+46.2 \%)$ until 2018. Similarly, Google Trends indices in the Eurotransplant region exhibited a decline in numbers in all Eurotransplant countries across the same period (Figure 2; Tables 2 and 3).

Figure 1. Worldwide interest in liver transplantation using Google Trends.

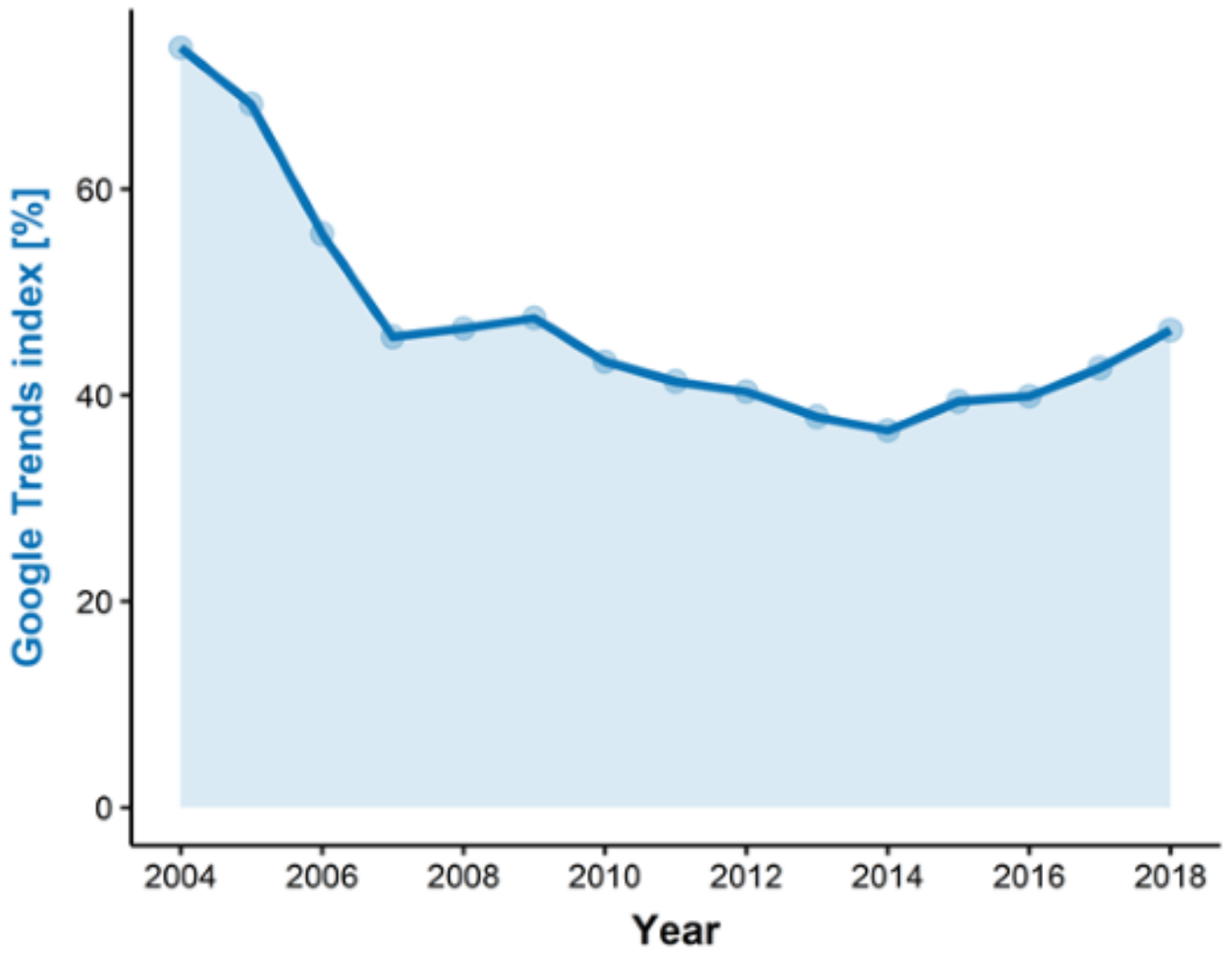


Figure 2. Google Trends and number of liver transplants in Eurotransplant, United Network for Organ Sharing, and Organización Nacional de Trasplantes over time.
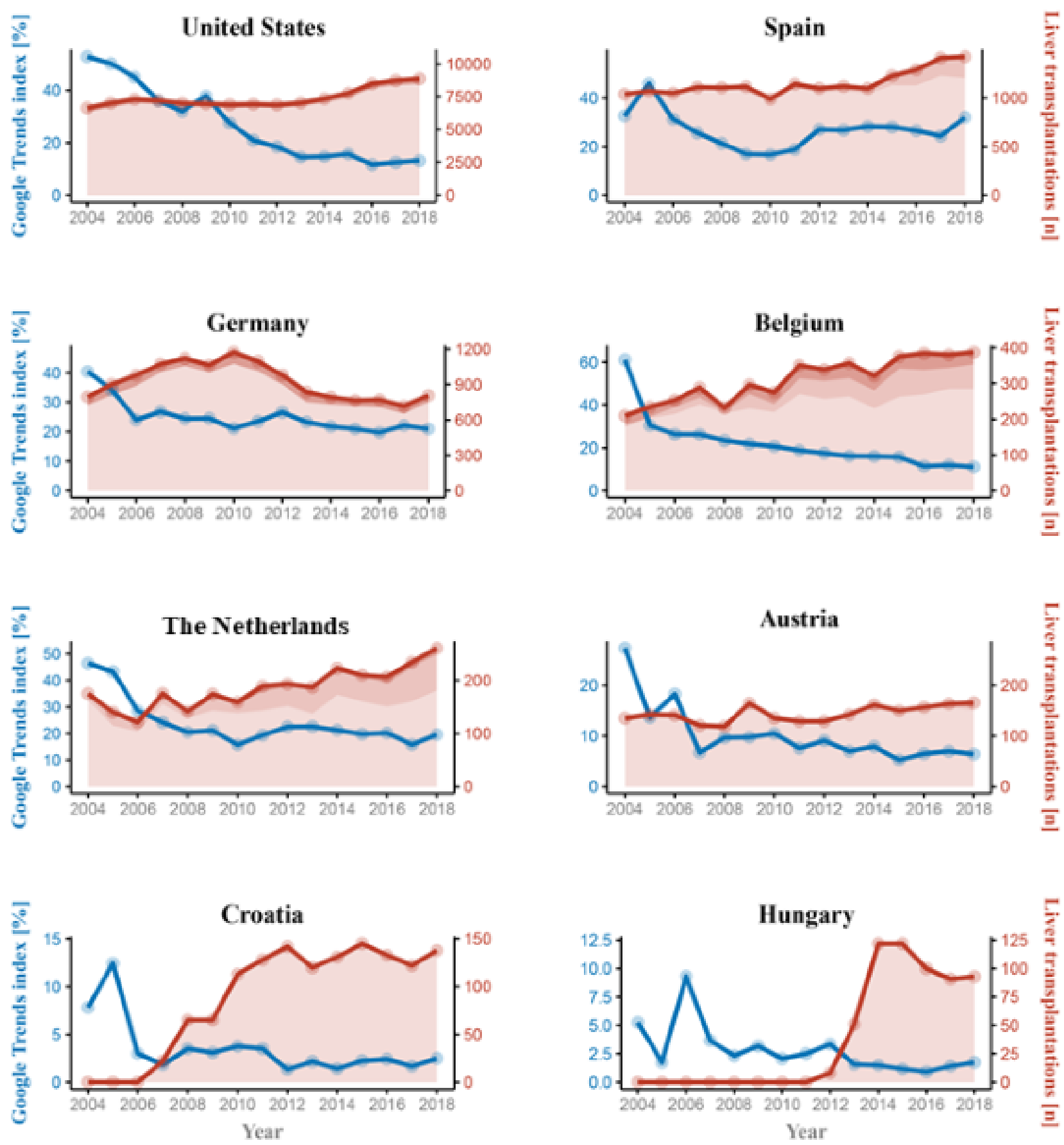
Table 2. The respective year, number of search queries using Google Trends, and the total number of liver transplantations performed in different countries are provided (deceased donor and living donor).

\begin{tabular}{|c|c|c|c|c|c|c|c|c|c|c|}
\hline Year & $\begin{array}{l}\text { World } \\
\text { Google } \\
\text { Trends in- } \\
\text { dex }\end{array}$ & $\begin{array}{l}\text { United } \\
\text { States } \\
\text { Google } \\
\text { Trends }\end{array}$ & $\begin{array}{l}\text { United } \\
\text { States } \mathrm{TX}^{\mathrm{a}} \\
\text { total }\end{array}$ & $\begin{array}{l}\text { Spain Google } \\
\text { Trends index }\end{array}$ & $\begin{array}{l}\text { Spain TX } \\
\text { total }\end{array}$ & $\begin{array}{l}\text { Belgium } \\
\text { Google } \\
\text { Trends index }\end{array}$ & $\begin{array}{l}\text { Belgium } \\
\text { TX total }\end{array}$ & $\begin{array}{l}\text { Luxem- } \\
\text { bourg TX } \\
\text { total }\end{array}$ & $\begin{array}{l}\text { The Nether- } \\
\text { lands Google } \\
\text { Trends index }\end{array}$ & $\begin{array}{l}\text { The } \\
\text { Nether- } \\
\text { lands TX } \\
\text { total }\end{array}$ \\
\hline 2004 & 73.8 & 59.1667 & 6642 & 8.3 & 1040 & 22.8 & 210 & 1 & 19.7 & 175 \\
\hline 2005 & 68.3 & 60.5833 & 7015 & 24.1 & 1070 & 11.9 & 234 & 2 & 5.3 & 140 \\
\hline 2006 & 55.7 & 49.3333 & 7302 & 12.2 & 1051 & 16.3 & 253 & 5 & 6.4 & 121 \\
\hline 2007 & 45.7 & 45.9167 & 7202 & 6.0 & 1112 & 8.6 & 288 & 1 & 5.7 & 175 \\
\hline 2008 & 46.5 & 45.25 & 7000 & 10.3 & 1108 & 13.4 & 232 & 0 & 5.5 & 141 \\
\hline 2009 & 47.5 & 52.0833 & 6958 & 6.3 & 1119 & 16.6 & 296 & 0 & 10.8 & 174 \\
\hline 2010 & 43.3 & 43.3333 & 6893 & 8.9 & 989 & 10.4 & 275 & 3 & 8.0 & 159 \\
\hline 2011 & 41.3 & 41.8333 & 6931 & 7.6 & 1145 & 12.5 & 351 & 9 & 8.6 & 189 \\
\hline 2012 & 40.3 & 40.0833 & 6876 & 13.4 & 1101 & 10.1 & 339 & 4 & 11.5 & 193 \\
\hline 2013 & 37.9 & 38.1667 & 7026 & 13.8 & 1122 & 12.3 & 357 & 6 & 8.1 & 187 \\
\hline 2014 & 36.6 & 38.0833 & 7344 & 13.3 & 1100 & 10.3 & 321 & 3 & 9.7 & 223 \\
\hline 2015 & 39.4 & 39.9167 & 7775 & 17.7 & 1229 & 11.3 & 375 & 3 & 9.3 & 210 \\
\hline 2016 & 39.9 & 39.75 & 8497 & 15.3 & 1292 & 11.4 & 384 & 3 & 9.3 & 207 \\
\hline 2017 & 42.7 & 43.9167 & 8740 & 14.3 & 1413 & 9.8 & 380 & 9 & 8.1 & 234 \\
\hline 2018 & 46.3 & 50.25 & 8875 & 17.3 & 1426 & 11.8 & 387 & 7 & 9.0 & 261 \\
\hline
\end{tabular}

${ }^{\mathrm{a}} \mathrm{TX}$ : number of transplantations.

Table 3. The respective year, number of search queries using Google Trends, and the total number of liver transplantations performed are provided (deceased donor and living donor).

\begin{tabular}{|c|c|c|c|c|c|c|c|c|c|}
\hline Year & $\begin{array}{l}\text { Germany } \\
\text { Google } \\
\text { Trends in- } \\
\text { dex }\end{array}$ & $\begin{array}{l}\text { Germany } \\
\mathrm{TX}^{\mathrm{a}} \text { total }\end{array}$ & $\begin{array}{l}\text { Austria Google } \\
\text { Trends index }\end{array}$ & $\begin{array}{l}\text { Austria TX } \\
\text { total }\end{array}$ & $\begin{array}{l}\text { Slovenia } \\
\text { TX total }\end{array}$ & $\begin{array}{l}\text { Hungary } \\
\text { Google Trends } \\
\text { index }\end{array}$ & $\begin{array}{l}\text { Hungary } \\
\text { TX total }\end{array}$ & $\begin{array}{l}\text { Croatia } \\
\text { Google } \\
\text { Trends index }\end{array}$ & $\begin{array}{l}\text { Croatia TX } \\
\text { total }\end{array}$ \\
\hline 2004 & 61.6 & 795 & 15.5 & 135 & 24 & 0.0 & 0 & 8.3 & 0 \\
\hline 2005 & 52.0 & 901 & 14.6 & 142 & 15 & 0.0 & 0 & 8.3 & 0 \\
\hline 2006 & 35.3 & 979 & 6.9 & 141 & 21 & 8.3 & 0 & 0.0 & 0 \\
\hline 2007 & 32.6 & 1074 & 16.2 & 121 & 15 & 1.4 & 0 & 0.8 & 22 \\
\hline 2008 & 35.8 & 1122 & 11.7 & 119 & 22 & 1.0 & 0 & 1.5 & 65 \\
\hline 2009 & 35.3 & 1065 & 9.4 & 165 & 22 & 2.2 & 0 & 2.0 & 65 \\
\hline 2010 & 29.2 & 1173 & 8.8 & 135 & 34 & 0.6 & 0 & 1.7 & 113 \\
\hline 2011 & 33.6 & 1097 & 11.8 & 129 & 24 & 2.2 & 0 & 1.3 & 128 \\
\hline 2012 & 36.3 & 980 & 12.9 & 129 & 38 & 1.8 & 8 & 1.2 & 142 \\
\hline 2013 & 31.8 & 836 & 9.8 & 142 & 35 & 1.3 & 51 & 1.9 & 120 \\
\hline 2014 & 30.1 & 793 & 9.3 & 162 & 34 & 1.2 & 122 & 1.0 & 131 \\
\hline 2015 & 27.9 & 765 & 5.6 & 150 & 43 & 1.3 & 122 & 2.3 & 145 \\
\hline 2016 & 27.3 & 771 & 7.3 & 157 & 37 & 0.8 & 100 & 1.3 & 133 \\
\hline 2017 & 30.3 & 716 & 11.2 & 164 & 34 & 1.3 & 91 & 1.8 & 122 \\
\hline 2018 & 27.3 & 807 & 6.5 & 166 & 29 & 1.9 & 93 & 2.3 & 138 \\
\hline
\end{tabular}

${ }^{\mathrm{a}} \mathrm{TX}$ : number of transplantations. 
In the same period (2004-2018), UNOS reported the most significant increase in deceased donor liver transplants from 6642 to $8875(+34.0 \%)$. Conversely, the number of living donor donations remained stable during the same period. The number of LTs increased by $24.0 \%$ and $18.2 \%$ in the Eurotransplant and ONT, respectively (Figure 3; Multimedia Appendix 1), and the number of (both deceased and live donor) LTs increased by $24.0 \%$ and $18.2 \%$ in the Eurotransplant and ONT, respectively (Figure 3; Multimedia Appendix 1).

Figure 3. Number of liver transplants in Eurotransplant, United Network for Organ Sharing, and Organización Nacional de Trasplantes. AUT: Austria; B: Belgium; CRO: Croatia; ESP: Spain; GER: Germany; GT: Google Trends; H: Hungary; NL: the Netherlands; TX: nuber of transplantations; US: United States.

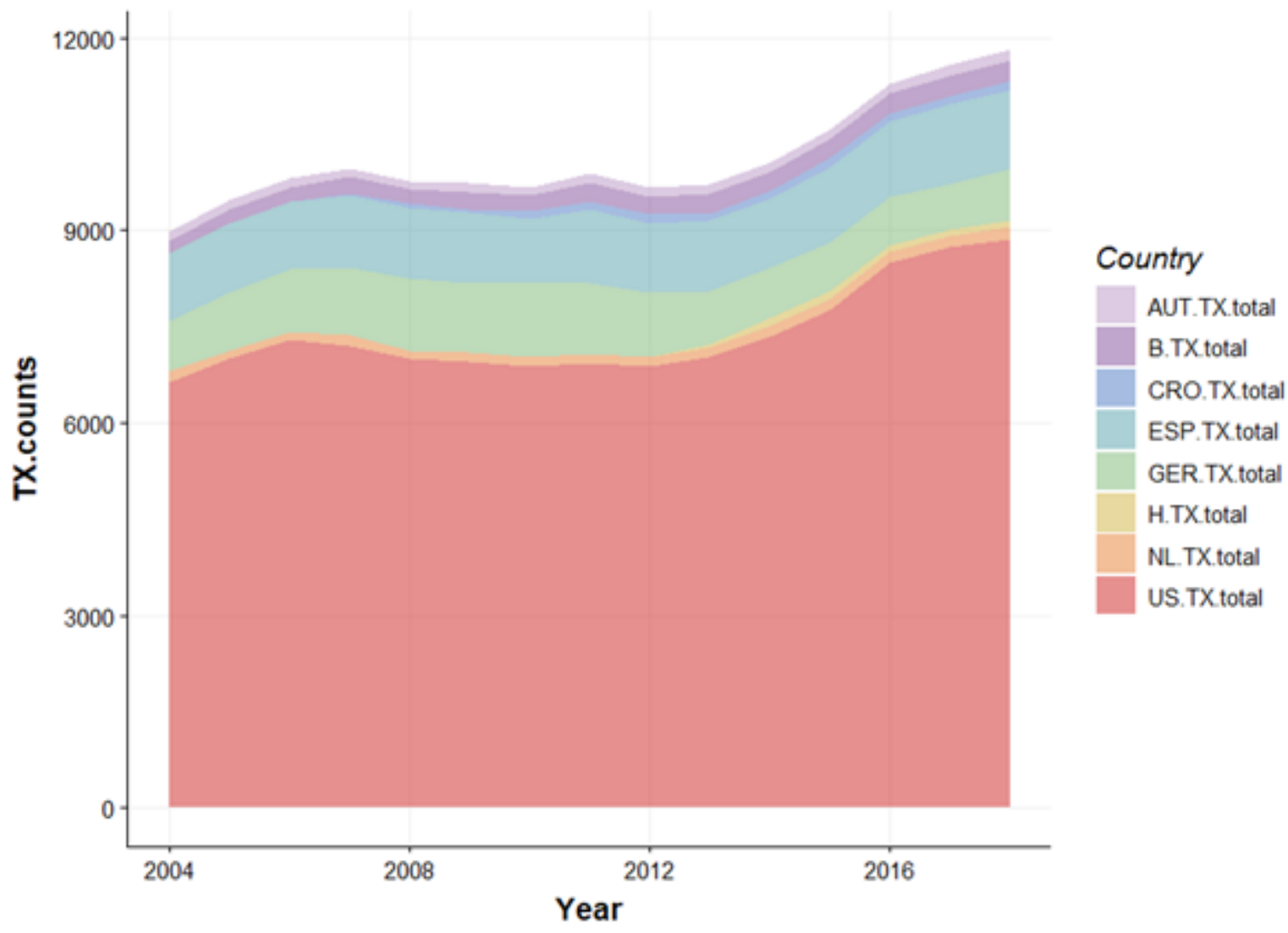

Belgium and the Netherlands were the only 2 countries in the Eurotransplant region with a mild increase in living donor LT; however, in these countries, a significant decrease in the Google Trends index was observed (Belgium: $-48.3 \%$; the Netherlands: $-53.3 \%$; Multimedia Appendix 2). Similar downward trends were observed in all Eurotransplant countries. A correlogram of the total transplant numbers and Google Trends indices of the investigated countries are depicted in Figure 4. Most notably, even in Croatia, a country with 42 transplantations per million and a dissent solution, the Google Trends index significantly decreased from 7.8 to $2.5(-75.7 \%)$. Google Trends changes and the number of transplants (deceased donor and living donor transplantations) in the respective countries over time are displayed in Figure 2. The number of DCDD donors in the Eurotransplant region and the UNOS area showed a mild increase. In 2018, only 8.08\% (145/1795) and 5.71\% (537/9412) of deceased donors were DCDD donors for LT in the Eurotransplant and UNOS regions, respectively (Multimedia Appendix 3). 
Figure 4. Correlogram of total transplant numbers and Google Trends indices of investigated countries. Correlations are based on the Spearman correlation coefficient. Pairwise correlations between total transplant numbers per country and Google Trends indices were calculated. Significant correlations with $P$ values <.05 and <.001 are highlighted by a colorful background in the upper and lower half of the matrix, respectively. AUT: Austria; B: Belgium; CRO: Croatia; ESP: Spain; GER: Germany; GT: Google Trends; H: Hungary; NL: the Netherlands; TX: nuber of transplantations; US: United States.

\section{Correlogram of transplantations and GT indices}

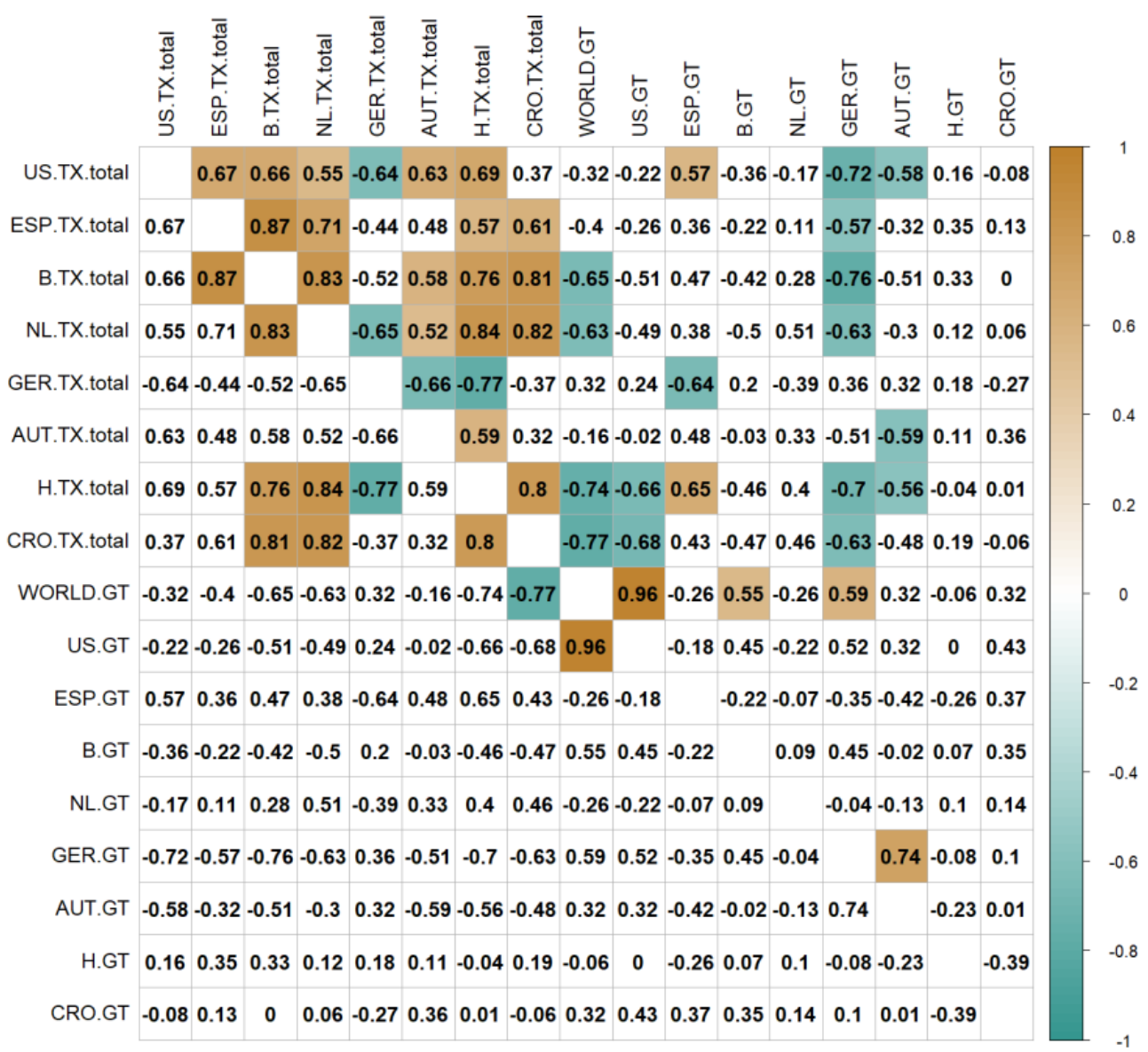

\section{Google Trends and Waiting List Mortality}

The waiting list mortality did not change significantly in UNOS $(-5.2 \%)$ and Eurotransplant (-6.2\%; Multimedia Appendix 4) regions. Even in Germany, the Eurotransplant country with the highest waiting list mortality $(451 / 1379,32.7 \%)$, the Google Trends index decreased from 40.4 to 21.1 ( $-48.5 \%$ ). Furthermore, we analyzed the data of UNOS based on ethnicity. With no significant change over time, Hispanic individuals (2.4\%), and American Indians and Alaska Natives (each 4.8\%), had a significantly higher mortality on the waiting list than that of all ethnicities (Multimedia Appendix 5). An overview of changes in Google Trends over time, number of transplants (deceased donor, DCDD, and living donor transplantation) in the respective countries is depicted in Figure 3.

\section{Google Trends and LT Program in Spain}

Spain exhibited a distinct Google Trends index pattern compared to other countries. The index slightly decreased until 2011 (the year of implementation of the DCDD program in Spain). A campaign for DCDD donors in the public, as well as in hospitals where potential donors are hospitalized, resulted in an increase in the Google Trends index. In the period of 15 years, we could not find a significant decrease in the Google Trends index
$(-1.8 \%)$. In fact, the number of transplanted livers increased because of DCDD by $18.1 \%$. Moreover, there was a decrease in waiting list mortality between 2011 and 2012 (-4.7\%). The overall waiting list mortality, too sick to transplant, and the dropout rate for other reasons were also significantly lower in Spain $(15 \%)$ than in UNOS $(31 \%)$ or Eurotransplant (29\%; Multimedia Appendix 5).

\section{Discussion}

\section{Principal Findings}

In this study, we found a significant decrease in Google Trends search queries for LT in the UNOS and Eurotransplant regions. As such, public and health care providers' levels of awareness regarding LT are decreasing alarmingly. In Spain, the leading country for transplantation, these findings were not as pronounced. Furthermore, the dropout rate in Spain was significantly lower than that in UNOS and Eurotransplant. Although the need for LT, as the only curative option for chronic liver disease, is increasing, the number of donor organs is also increasing. However, the gap between possible recipients and donors is also increasing. To close this gap, transplant and donor programs, which in part bring awareness to both the public and health care domains, may provide some improvement. 
As indicated by the compelling findings presented here, the application of internet data in health care research presents a promising new field. It may further complement and extend the current data sources and foundations [43]. Approximately $90 \%$ of US citizens use the internet regularly. According to a data analysis of Pew Research Center (Washington, DC), following an ongoing rapid growth of going online and use of social media in the United States over the last decade, it stayed stable over the past 3 years. Comparable data are available in Europe.

Health and health care were the number 2 priorities to the US public in 2019. Internet users tend to search for health-related topics accordingly. In fact, more than $80 \%$ of all internet users look for health information on the web. Among them, 66\% searched for information concerning a specific disease or medical problem (perennially the most popular purpose), and $56 \%$ were interested in a certain medical treatment or procedure. After checking emails and using search engines, looking for health topics was the third most frequent activity on the internet. Interestingly, the typical search for health information is on behalf of someone else [44]. The most popular science Facebook group boasts up to 44 million followers [45]. Limited access to internet use, especially internet search for health-related topics, has been found in minorities such as Hispanic, American Indian, and Alaska Native (PEW Research Center). This finding might in part explain the higher mortality and morbidity rates in these ethnicities compared with other ethnicities. Although health care topics on the internet are constantly rising, interest in LT has been decreasing since 2014 all over the world. This trend indicates that the topic LT is underrepresented in the web, despite a small increase seen from 2014 onward. However, the internet (eg, search engines and social media) is the largest platform for awareness programs in the field of liver disease and LT.

To date, very little is published regarding the awareness of LT. This disparity between the low search volumes of the terms relating to LT and the actual increasing number of transplantations may originate in the established low awareness campaigns of LT. Such campaigns are highly useful, as past awareness movements have proved extremely effective. For example, the Ice Bucket Challenge promoted awareness of amyotrophic lateral sclerosis. This activity, demonstrated by the dumping of a bucket of ice water over a person's head, went viral in the summer of 2014 and resulted in a nearly 1000-fold increase in the Google Trends index. Subsequently, over US $\$ 220$ million in funding has been raised worldwide for this rare disease. Several awareness campaigns related to other health issues in recent years have also proved immensely successful. One of the best known includes the Red Ribbon movement to fight HIV infection. Even a World AIDS Day was initiated on December 1, 1988 [46]. Other programs, such as those promoting the fight against breast cancer, were followed with significant successes in both awareness and funding. An additional notable example is the Jade Ribbon Campaign, which was a great success in hepatitis B virus awareness, screening, and physician follow-ups in Chinese Americans. Conversely, the term liver disease is strongly underrepresented in the public awareness and, in turn, the World Health Organization's goal to eradicate hepatitis $\mathrm{C}$ by 2030 will most likely not be achieved.
Even in well-developed countries, there is too little awareness of this disease among health care providers and the broad public [47]. The LT field was even more underrepresented. The reasons for this dearth of awareness are two-fold. The knowledge of primary care providers regarding the possibilities of LT remains insufficient. However, patients complain about a lack of information related to the nature of their disease and the potential to undergo LT.

As shown from past promotion campaigns of various other diseases, public awareness should be the key goal to increase organ donation rates. Spain's case offers evidence of such contention. The overwhelming number of 43.4 donors per million population in the country (2016) reflects the increased level of information provided to the public regarding organ donation. Close attention to the mass media is a key point of the Spanish system and serves a preeminent way to inform the public and raise awareness. As a result of Spain's communication policy, journalists have become extremely important in promoting organ donation. This topic is massive and continuously presented in the media. In 2016, a total of 155 Spanish media reports or news on the topic transplantation were on TV, radio, and printed press releases on the European organ donation day in October. The internet and social media were not included in the survey. The estimated audience comprised 24 million people [48]. Thus, the interest in LT in Spain has remained high over the past 16 years.

In addition, it is important to note that the number of DCDD LTs has increased significantly over the last few years in Spain. This increase in LTs, including DCDD, might reflect the success of awareness campaigns by the ONT. The ONT has established awareness programs across the country, subject to the national Spanish health ministry. Hepatologists and anesthesiologists with special training in the field of LT are representatives of transplantation programs [49]. The fruits of this work were visible in our Google Trends analysis. Specifically, there were increased search rates of the topic, liver transplantation, in Spain, alongside increased number of donors, transplantations, and a lower mortality rate on the waiting list. Thus, we conclude that a stable Google Trends index, compared with the global trend, reflects the success story in Spain. This underlines our hypothesis that sensitizing people for the topic could close the gap between supply and demand in LT. Furthermore, the worldwide increase of the search terms liver transplantation and liver transplant since 2014 may be because of more awareness programs, as well as an increasing number of DCDD and living donor transplants worldwide. Indeed, steps to increase awareness are underway. For example, the first National Patient Advisory Committee of America's Liver Foundation was founded. At present, more than 50 diverse members are trained to raise awareness of the field of LT across the United States. In 2015, legislators were educated about LT and liver disease. Such discussions resulted in an annual Advocacy Day, which allowed for more awareness and an increase in search terms in the United States and worldwide.

The impact of web-based research has grown continuously in the past decade [50]. To date, Google Trends is the only unbiased approach that includes millions of users and has been widely used in economics and health issues. In economics, 
Google Trends data can help to improve forecasts of the current level of activity for a number of different economic time series such as automobile sales, retail sales, or unemployment [51,52]. Economists have already been at work using Google Trends to make quantitative forecasts [51,53]. Several recent research publications demonstrate that data on web searches from Google Trends can improve the accuracy of forecasts over conventional models. The use of Google data has rapidly spread in the literature to predict other economic indicators, such as analyzing their impact on stock markets and studying bond markets or their impact on commodities [54,55]. Goggle Trends and the field of infodemiology are being widely used in the field of health-related issues as well. Public attention in different fields of health care has been published recently (eg, osteoarthritis, breast cancer, or chronic inflammatory lung disease) [34,56,57]. Furthermore, infodemiology and Google Trends are used to generate awareness profiles and are suitable substitutes for classical data collection, such as surveys [50]. Thus far, Google Trends has been primarily used to monitor disease control and awareness in cancer, HIV, or stroke and also in rare diseases such as antiphospholipid syndrome or systemic lupus erythematosus [35,58-60]. Google Trends offers a wide range of capabilities, with one being the detection of success rates of awareness programs $[61,62]$.

\section{Limitations}

Our data indicate multiple novel aspects in the field of LT, such as those concerning donor and recipient awareness. Nonetheless, as with any study, there are some potential limitations. Data should be interpreted with caution in the context of public health and disease awareness. Rationale is 2-fold. First, there was no information about individual searches for the analyzed topics. A bias related to a high number of search queries by health care professionals, industry, or marketing agencies cannot be excluded. Second, it is to some extent elusive which search queries are summarized in the topics defined by Google Trends algorithms, as detailed information on how Google generates these data is not provided. The selection of spelling or terms might affect the results and conclusions; therefore, we chose to use more accurate spelling by native speakers and provide a detailed description of our data-gathering approach to facilitate reproducibility. Misspellings, slang words, or different accent use were considered; foreign languages (eg, English and official languages of neighboring countries) were not taken into consideration. Furthermore, some countries (eg, Hungary and Luxembourg) have a lower number of inhabitants, thus resulting in a small sample size for these countries. This may result in huge variations in Google Trends analyses over time. Another limitation may concern rural areas, as they tend to have limited internet access. Moreover, the internet use of the term liver transplantation is low in some countries and their official languages. The importance of accuracy in defining search queries is exemplified by searching Google Trends for the topic immunosuppressants. Although not specifically representing LT, immunosuppressants are associated with LT. Hence, using the query immunosuppressant may be useful to analyze symptom-related interest but does not sufficiently represent LT awareness. Finally, the number of studies based on Google Trends has been increasing, but so far, there is no standardized procedure for data collection. More guidance by Google is warranted to assist researchers in establishing an optimal search strategy [63].

\section{Conclusions}

Google Trends provides a powerful tool for evaluating public interest related to LT and associated liver diseases. According to our study, interest in LT has decreased over the last decade in all investigated countries except Spain. The success story in Spain is encouraging, as it confirms that more awareness campaigns in the field of LT are needed to close the gap between increasing demand and a small supply of potential donor organs. Therefore, international awareness programs are required. In the future, the effects of awareness programs could be evaluated using Google Trends. In line with the goal of higher awareness for solid organ transplantation, Google Trends helps to collect, analyze, report, and disseminate LT-related health data. Google Trends may, therefore, not only drive change and track progress but may also help to improve programs to counteract the current lack of public LT awareness.

\section{Acknowledgments}

This work was supported by the Excellence Initiative VASCage (Centre for Promoting Vascular Health in the Ageing Community), a research and development K-Centre (COMET [Competence Centers for Excellent Technologies] program) funded by the Austrian Ministry for Transport, Innovation and Technology, the Austrian Ministry for Digital and Economic Affairs, and the federal states Tyrol, Salzburg, and Vienna.

\section{Conflicts of Interest}

None declared.

\section{Multimedia Appendix 1}

Liver transplant numbers per country and year.

[PDF File (Adobe PDF File), 134 KB-Multimedia Appendix 1]

\section{Multimedia Appendix 2}

Living, deceased, and donation after circulatory determination of death donors in Eurotransplant by country. [PDF File (Adobe PDF File), 147 KB-Multimedia Appendix 2] 


\section{Multimedia Appendix 3}

Living, deceased, and donation after circulatory determination of death donors in Eurotransplant, United Network for Organ Sharing, and Organización Nacional de Trasplantes.

[PDF File (Adobe PDF File), 128 KB-Multimedia Appendix 3]

\section{Multimedia Appendix 4}

Liver waiting list removal due to death, too sick to transplant, died during transplant, and others.

[PDF File (Adobe PDF File), $161 \mathrm{~KB}-$ Multimedia Appendix 4]

\section{Multimedia Appendix 5}

United Network for Organ Sharing data on death removal by ethnicity by year in percentages (\%).

[PDF File (Adobe PDF File), 147 KB-Multimedia Appendix 5]

\section{References}

1. Thapar M, Bonkovsky HL. Indications for liver transplant and AASLD guidelines. Hepatology 2015 Jan;61(1):408. [doi: 10.1002/hep.27176] [Medline: 24752818]

2. European Association for the Study of the Liver. EASL Clinical Practice Guidelines: Liver transplantation. J Hepatol 2016 Feb;64(2):433-485. [doi: 10.1016/j.jhep.2015.10.006] [Medline: 26597456]

3. Agopian VG, Petrowsky H, Kaldas FM, Zarrinpar A, Farmer DG, Yersiz H, et al. The evolution of liver transplantation during 3 decades: analysis of 5347 consecutive liver transplants at a single center. Ann Surg 2013 Sep;258(3):409-421. [doi: 10.1097/SLA.0b013e3182a15db4] [Medline: 24022434]

4. Adam R, Karam V, Delvart V, O'Grady J, Mirza D, Klempnauer J, All contributing centers (www.eltr.org), European LiverIntestine Transplant Association (ELITA). Evolution of indications and results of liver transplantation in Europe. A report from the European Liver Transplant Registry (ELTR). J Hepatol 2012 Sep;57(3):675-688 [FREE Full text] [doi: 10.1016/j.jhep.2012.04.015] [Medline: 22609307]

5. Dutkowski P, De Rougemont O, Müllhaupt B, Clavien P. Current and future trends in liver transplantation in Europe. Gastroenterology 2010 Mar;138(3):802-809. [doi: 10.1053/j.gastro.2010.01.030] [Medline: 20096694]

6. Dutkowski P, Linecker M, DeOliveira ML, Müllhaupt B, Clavien P. Challenges to liver transplantation and strategies to improve outcomes. Gastroenterology $2015 \mathrm{Feb} ; 148(2): 307-323$. [doi: 10.1053/j.gastro.2014.08.045] [Medline: 25224524]

7. Kwong A, Kim WR, Lake JR, Smith JM, Schladt DP, Skeans MA, et al. OPTN/SRTR 2018 Annual Data Report: Liver. Am J Transplant 2020 Jan;20 Suppl s1:193-299. [doi: 10.1111/ajt.15674] [Medline: $\underline{\text { 31898413] }}$

8. Fayek SA, Quintini C, Chavin KD, Marsh CL. The current state of liver transplantation in the United States: perspective from American Society of Transplant Surgeons (ASTS) Scientific Studies Committee and Endorsed by ASTS Council. Am J Transplant 2016 Nov;16(11):3093-3104 [FREE Full text] [doi: 10.1111/ajt.14017] [Medline: 27545282]

9. Samuel D, Coilly A. Management of patients with liver diseases on the waiting list for transplantation: a major impact to the success of liver transplantation. BMC Med 2018 Aug 01;16(1):113 [FREE Full text] [doi: 10.1186/s12916-018-1110-y] [Medline: $\underline{30064414]}$

10. Müllhaupt B, Dimitroulis D, Gerlach JT, Clavien P. Hot topics in liver transplantation: organ allocation - extended criteria donor - living donor liver transplantation. J Hepatol 2008;48 Suppl 1:58-67 [FREE Full text] [doi: 10.1016/j.jhep.2008.01.013] [Medline: 18308415$]$

11. Boteon YL, Laing RW, Schlegel A, Wallace L, Smith A, Attard J, et al. Combined hypothermic and normothermic machine perfusion improves functional recovery of extended criteria donor livers. Liver Transpl 2018 Dec;24(12):1699-1715 [FREE Full text] [doi: 10.1002/lt.25315] [Medline: $\underline{30058119}$ ]

12. Giorgakis E, Khorsandi SE, Jassem W, Heaton N. DCD consensus and futility in liver transplantation. J Hepatol 2018 Jul;69(1):255-256. [doi: 10.1016/j.jhep.2018.03.032] [Medline: 29655976]

13. Eysenbach G. Infodemiology: The epidemiology of (mis)information. Am J Med 2002 Dec 15;113(9):763-765. [doi: 10.1016/s0002-9343(02)01473-0] [Medline: 12517369]

14. Eysenbach G. Infodemiology and infoveillance: framework for an emerging set of public health informatics methods to analyze search, communication and publication behavior on the internet. J Med Internet Res 2009;11(1):e11 [FREE Full text] [doi: 10.2196/jmir.1157] [Medline: 19329408]

15. Eysenbach G. How to fight an infodemic: the four pillars of infodemic management. J Med Internet Res 2020 Jun 29;22(6):e21820 [FREE Full text] [doi: 10.2196/21820] [Medline: 32589589]

16. Eysenbach G. Infodemiology and infoveillance tracking online health information and cyberbehavior for public health. Am J Prev Med 2011 May;40(5 Suppl 2):154-158. [doi: 10.1016/j.amepre.2011.02.006] [Medline: 21521589]

17. Eysenbach G. Infodemiology: tracking flu-related searches on the web for syndromic surveillance. AMIA Annu Symp Proc 2006:244-248 [FREE Full text] [Medline: 17238340 ] 
18. Mavragani A. Infodemiology and infoveillance: scoping review. J Med Internet Res 2020 Apr 28;22(4):e16206 [FREE Full text] [doi: 10.2196/16206] [Medline: 32310818]

19. Adrover C, Bodnar T, Huang Z, Telenti A, Salathé M. Identifying adverse effects of HIV drug treatment and associated sentiments using Twitter. JMIR Public Health Surveill 2015;1(2):e7 [FREE Full text] [doi: 10.2196/publichealth.4488] [Medline: 27227141]

20. Zheluk A, Quinn C, Hercz D, Gillespie JA. Internet search patterns of human immunodeficiency virus and the digital divide in the Russian Federation: infoveillance study. J Med Internet Res 2013;15(11):e256 [FREE Full text] [doi: 10.2196/jmir.2936] [Medline: 24220250]

21. Mavragani A, Ochoa G. Forecasting AIDS prevalence in the United States using online search traffic data. J Big Data 2018 May 19;5(1):5. [doi: 10.1186/s40537-018-0126-7]

22. Koschack J, Weibezahl L, Friede T, Himmel W, Makedonski P, Grabowski J. Scientific versus experiential evidence: discourse analysis of the chronic cerebrospinal venous insufficiency debate in a multiple sclerosis forum. J Med Internet Res 2015 Jul 01;17(7):e159 [FREE Full text] [doi: 10.2196/jmir.4103] [Medline: 26133525]

23. Risson V, Saini D, Bonzani I, Huisman A, Olson M. Patterns of treatment switching in multiple sclerosis therapies in US patients active on social media: application of social media content analysis to health outcomes research. J Med Internet Res 2016;18(3):e62 [FREE Full text] [doi: 10.2196/jmir.5409] [Medline: 26987964]

24. Rose SW, Jo CL, Binns S, Buenger M, Emery S, Ribisl KM. Perceptions of menthol cigarettes among Twitter users: content and sentiment analysis. J Med Internet Res 2017 Feb 27;19(2):e56 [FREE Full text] [doi: 10.2196/jmir.5694] [Medline: 28242592]

25. Duke JC, Hansen H, Kim AE, Curry L, Allen J. The use of social media by state tobacco control programs to promote smoking cessation: a cross-sectional study. J Med Internet Res 2014;16(7):e169 [FREE Full text] [doi: 10.2196/jmir.3430] [Medline: 25014311]

26. Yom-Tov E, Gabrilovich E. Postmarket drug surveillance without trial costs: discovery of adverse drug reactions through large-scale analysis of web search queries. J Med Internet Res 2013;15(6):e124 [FREE Full text] [doi: 10.2196/jmir.2614] [Medline: 23778053]

27. Santos JC, Matos S. Analysing Twitter and web queries for flu trend prediction. Theor Biol Med Model 2014 May 07;11 Suppl 1:S6 [FREE Full text] [doi: 10.1186/1742-4682-11-S1-S6] [Medline: 25077431]

28. Effenberger M, Kronbichler A, Shin JI, Mayer G, Tilg H, Perco P. Association of the COVID-19 pandemic with internet search volumes: a Google Trends Analysis. Int J Infect Dis 2020 Jun;95:192-197 [FREE Full text] [doi:

10.1016/j.ijid.2020.04.033] [Medline: 32305520]

29. Nsoesie EO, Cesare N, Müller M, Ozonoff A. COVID-19 Misinformation spread in eight countries: exponential growth modeling study. J Med Internet Res 2020 Dec 15;22(12):e24425 [ [FREE Full text] [doi: 10.2196/24425] [Medline: 33264102]

30. Mavragani A. Tracking COVID-19 in Europe: Infodemiology approach. JMIR Public Health Surveill 2020 Apr 20;6(2):e18941 [FREE Full text] [doi: 10.2196/18941] [Medline: 32250957]

31. Jacobson NC, Lekkas D, Price G, Heinz MV, Song M, O'Malley AJ, et al. Flattening the mental health curve: COVID-19 stay-at-home orders are associated with alterations in mental health search behavior in the United States. JMIR Ment Health 2020 Jun 01;7(6):e19347. [doi: 10.2196/19347] [Medline: 32459186]

32. Hong Y, Lawrence J, Williams D, Mainous I. Population-level interest and telehealth capacity of US hospitals in response to COVID-19: cross-sectional analysis of Google search and National Hospital Survey Data. JMIR Public Health Surveill 2020 Apr 07;6(2):e18961 [FREE Full text] [doi: 10.2196/18961] [Medline: 32250963]

33. Arora VS, McKee M, Stuckler D. Google Trends: Opportunities and limitations in health and health policy research. Health Policy 2019 Mar;123(3):338-341. [doi: 10.1016/j.healthpol.2019.01.001] [Medline: 30660346]

34. Kaleem T, Malouff TD, Stross WC, Waddle MR, Miller DH, Seymour AL, et al. Google search trends in oncology and the impact of celebrity cancer awareness. Cureus 2019 Aug 10;11(8):e5360 [FREE Full text] [doi: 10.7759/cureus.5360] [Medline: 31608195]

35. Ling R, Lee J. Disease monitoring and health campaign evaluation using Google search activities for HIV and aids, stroke, colorectal cancer, and marijuana use in Canada: a retrospective observational study. JMIR Public Health Surveill 2016 Oct 12;2(2):e156 [FREE Full text] [doi: 10.2196/publichealth.6504] [Medline: 27733330]

36. Kronbichler A, Effenberger M, Shin JI, Koppelstätter C, Denicolò S, Rudnicki M, et al. Is there decreasing public interest in renal transplantation? A Google Trends Analysis. J Clin Med 2020 Apr 07;9(4):1048 [FREE Full text] [doi: 10.3390/jcm9041048] [Medline: $\underline{32272783}$ ]

37. Van de Belt TH, Engelen LJ, Berben SA, Teerenstra S, Samsom M, Schoonhoven L. Internet and social media for health-related information and communication in health care: preferences of the Dutch general population. J Med Internet Res 2013;15(10):e220 [FREE Full text] [doi: 10.2196/jmir.2607] [Medline: 24088272]

38. Ybarra ML, Suman M. Help seeking behavior and the internet: a national survey. Int J Med Inform 2006 Jan;75(1):29-41. [doi: 10.1016/j.ijmedinf.2005.07.029] [Medline: 16129659]

39. United Network for Organ Sharing (UNOS). URL: https://unos.org [accessed 2021-07-23]

40. National Transplant Organization (ONT). URL: http://www.ont.es [accessed 2021-07-23]

41. Eurotransplant. URL: https://www.eurotransplant.org [accessed 2021-07-23] 
42. Google Trends. URL: https://trends.google.com/trends [accessed 2021-07-23]

43. Mavragani A, Ochoa G. Google Trends in infodemiology and infoveillance: methodology framework. JMIR Public Health Surveill 2019 May 29;5(2):e13439 [FREE Full text] [doi: 10.2196/13439] [Medline: $\underline{31144671]}$

44. Gidwani R, Zulman D. Association between acute medical exacerbations and consuming or producing web-based health information: analysis from Pew Survey Data. J Med Internet Res 2015 Jun 23;17(6):e145 [FREE Full text] [doi: 10.2196/jmir.3801] [Medline: 26104000]

45. Li J, Theng Y, Foo S. Predictors of online health information seeking behavior: changes between 2002 and 2012 . Health Informatics J 2015 Aug 10:804-814. [doi: 10.1177/1460458215595851] [Medline: 26261218]

46. No authors listed. World AIDS Day - December 1, 2019. MMWR Morb Mortal Wkly Rep 2019 Nov 29;68(47):1089 [FREE Full text] [doi: 10.15585/mmwr.mm6847a1] [Medline: 31851652]

47. Schaefer B, Viveiros A, Al-Zoairy R, Blach S, Brandon S, Razavi H, et al. Disease burden of hepatitis C in the Austrian state of Tyrol - Epidemiological data and model analysis to achieve elimination by 2030. PLoS One 2018;13(7):e0200750 [FREE Full text] [doi: 10.1371/journal.pone.0200750] [Medline: 30001427]

48. Matesanz R, Marazuela R, Coll E, Mahíllo B, Domínguez-Gil B. About the opt-out system, live transplantation, and information to the public on organ donation in Spain ... Y olé!. Am J Transplant 2017 Jun;17(6):1695-1696 [FREE Full text] [doi: 10.1111/ajt.14296] [Medline: 28382792]

49. de la Rosa G, Fondevila C, Navasa M. Liver transplantation in Spain. Liver Transpl 2016 Sep;22(9):1259-1264 [FREE Full text] [doi: 10.1002/lt.24484] [Medline: 27197947]

50. Jun S, Yoo HS, Choi S. Ten years of research change using Google Trends: from the perspective of big data utilizations and applications. Technol Forecast Soc Change 2018 May;130:69-87. [doi: 10.1016/j.techfore.2017.11.009]

51. Fritzsch B, Wenger K, Sibbertsen P, Ullmann G. Can Google Trends improve sales forecasts on a product level? Appl Econ Lett 2019 Nov 01;27(17):1409-1414. [doi: 10.1080/13504851.2019.1686110]

52. Nagao S, Takeda F, Tanaka R. Nowcasting of the U.S. unemployment rate using Google Trends. Finance Res Lett 2019 Sep;30:103-109. [doi: 10.1016/j.frl.2019.04.005]

53. Bulut L. Google Trends and the forecasting performance of exchange rate models. J Forecast 2017 Nov 29;37(3):303-315. [doi: 10.1002/for.2500]

54. Peri M, Baldi L, Vandone D. Price discovery in commodity markets. Appl Econ Lett 2013 Mar;20(4):397-403. [doi: 10.1080/13504851.2012.709590]

55. Ben-Rephael A, Da Z, Israelsen R. It depends on where you search: institutional investor attention and underreaction to news. Review of financial studies. 2017 SEP 2017;30(9):3009-3047. [doi: 10.1093/rfs/hhx031]

56. Jellison SS, Bibens M, Checketts J, Vassar M. Using Google Trends to assess global public interest in osteoarthritis. Rheumatol Int 2018 Dec;38(11):2133-2136. [doi: 10.1007/s00296-018-4158-2] [Medline: $\underline{30218145]}$

57. Boehm A, Pizzini A, Sonnweber T, Loeffler-Ragg J, Lamina C, Weiss G, et al. Using Google Trends to investigate global COPD awareness. Eur Respir J 2019 Aug;54(2):1901339. [doi: 10.1183/13993003.01339-2019] [Medline: 31395673]

58. Mahroum N, Bragazzi NL, Brigo F, Waknin R, Sharif K, Mahagna H, et al. Capturing public interest toward new tools for controlling human immunodeficiency virus (HIV) infection exploiting data from Google Trends. Health Informatics J 2019 Dec 11;25(4):1383-1397 [FREE Full text] [doi: 10.1177/1460458218766573] [Medline: 29638172]

59. Sciascia S, Radin M, Unlu O, Erkan D, Roccatello D. Infodemiology of antiphospholipid syndrome: merging informatics and epidemiology. Eur J Rheumatol 2018 Jul;5(2):92-95 [FREE Full text] [doi: 10.5152/eurjrheum.2018.17105] [Medline: 30185355]

60. Sciascia S, Radin M. What can Google and Wikipedia can tell us about a disease? Big Data trends analysis in Systemic Lupus Erythematosus. Int J Med Inform 2017 Nov;107:65-69. [doi: 10.1016/j.ijmedinf.2017.09.002] [Medline: 29029693]

61. McLean S, Lennon P, Glare P. Internet search query analysis can be used to demonstrate the rapidly increasing public awareness of palliative care in the USA. BMJ Support Palliat Care 2019 Mar;9(1):40-44. [doi: 10.1136/bmjspcare-2016-001171] [Medline: 28130324]

62. Patel MS, Halpern JA, Desai AS, Keeter MK, Bennett NE, Brannigan RE. Success of prostate and testicular cancer awareness campaigns compared to breast cancer awareness month according to internet search volumes: a Google Trends Analysis. Urology 2020 May;139:64-70. [doi: 10.1016/j.urology.2019.11.062] [Medline: $\underline{\text { 32001306] }}$

63. Nuti SV, Wayda B, Ranasinghe I, Wang S, Dreyer RP, Chen SI, et al. The use of Google Trends in health care research: a systematic review. PLoS One 2014;9(10):e109583 [FREE Full text] [doi: 10.1371/journal.pone.0109583] [Medline: $\underline{25337815}$ ]

\section{Abbreviations}

DCDD: donation after circulatory determination of death

LT: liver transplantation

ONT: Organización Nacional de Trasplantes

UNOS: United Network for Organ Sharing 
Edited by R Kukafka; submitted 20.06.20; peer-reviewed by A Mavragani, T Cruvinel; comments to author 29.08.20; revised version received 23.10.20; accepted 21.06.21; published 17.08 .21

Please cite as:

Effenberger M, Kronbichler A, Bettac E, Grabherr F, Grander C, Adolph TE, Mayer G, Zoller H, Perco P, Tilg H

Using Infodemiology Metrics to Assess Public Interest in Liver Transplantation: Google Trends Analysis

$J$ Med Internet Res 2021;23(8):e21656

URL: https://www.jmir.org/2021/8/e21656

doi: $10.2196 / 21656$

PMID:

(CMaria Effenberger, Andreas Kronbichler, Erica Bettac, Felix Grabherr, Christoph Grander, Timon Erik Adolph, Gert Mayer, Heinz Zoller, Paul Perco, Herbert Tilg. Originally published in the Journal of Medical Internet Research (https://www.jmir.org), 17.08.2021. This is an open-access article distributed under the terms of the Creative Commons Attribution License (https://creativecommons.org/licenses/by/4.0/), which permits unrestricted use, distribution, and reproduction in any medium, provided the original work, first published in the Journal of Medical Internet Research, is properly cited. The complete bibliographic information, a link to the original publication on https://www.jmir.org/, as well as this copyright and license information must be included. 